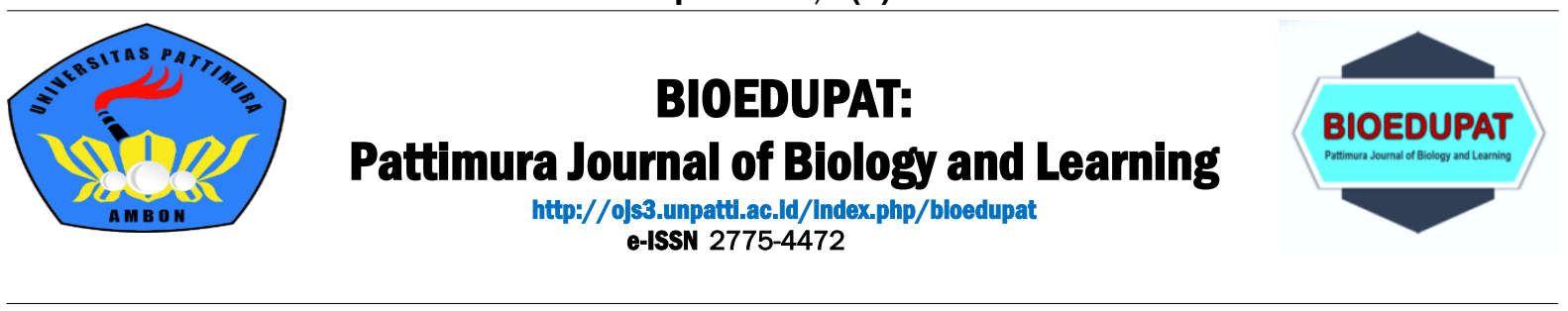

Research Article

\title{
The effect of black cumin oil (Nigella sativa) on the reproduction of male Wistar rats
}

\author{
Syahran Wael ${ }^{1}$, Didik Wahyudi², Tayeb Wael ${ }^{3}$, Zaid Mohamed Jaber ${ }^{*}$ \\ ${ }^{1}$ Department of Biology Education, Pattimura University, Street. Ir. M. Putuhena, Ambon 97233, Indonesia \\ ${ }^{2}$ Academy National of Health Analysts Surakarta. Street. Yos Sudarso, Solo 57155 Indonesia \\ ${ }^{3}$ Faculty of medicine of Tunis el Manar, Street. Rommana, Tunis 1068 Tunisia \\ ${ }^{4}$ Medical laboratories at Imhemed Ben Ibrahim Health Institute. Street. S-Khamis, Al-Khums 9506 Libya \\ *corresponding author: Zaid_mohamed@yahoo.com
}

Accepted: October 18, 2021

\begin{abstract}
Nigella sativa oil is antioxidant compound has the effect that serves to prevent cellular damage. The effect of Nigella sativa oil in the motility and total count of spermatozoa wistar rats. Experimental research with the design of post test only control group design. Wistar rats consists of 24 head and divided into 4 groups consist of control and treatment group. The control group was distilled. The first treatment was of Nigella sativa oil everydays as much with dose $150 \mathrm{mg} / \mathrm{kgbw}, 250 \mathrm{mg} / \mathrm{kgbw}$, and $350 \mathrm{mg} / \mathrm{kgbw}$, for 16 days, . Statistic test for motility and count of sperm wistar rats use the Kruskal-Wallis followed by Mann Whitney test. Avarage value of motility in the control (21.67 \pm 9.832$)$ its lower than treatment. In dose $350 \mathrm{mg} / \mathrm{kgbw}$ its highest (52.33 \pm 13.292$)$ compare in the treatment $250 \mathrm{mg} / \mathrm{kgbw}(40.67 \pm 17.512)$ and $150 \mathrm{mg} / \mathrm{kgbw}(30.67 \pm 8.165)$. avarage value of count sperm in the control $(130.83 \pm 41.877)$ its lower than treatments. In dose $350 \mathrm{mg} / \mathrm{kgbw}$ its highest $(199.67 \pm 23.480)$ compare in the treatment $250 \mathrm{mg} / \mathrm{kgbw}(187.50 \pm 74.538)$ and $150 \mathrm{mg} / \mathrm{kgbw}(140.83 \pm 32.568)$. Administration of Nigella sativa oil occur to enhancement motility and number of spermatozoa wistar rats.
\end{abstract}

Keywords: Nigella sativa, motility, count of spermatozoa

To cite this article:

Wael S., Wahyudi D., Wael T., \& Jaber Z.M. (2021). The effect of black cumin oil (Nigella sativa) on the reproduction of male Wistar rats. Bioedupat: Pattimura Journal of Biology and Learning, Vol 1 (2), 45-49.

DOI: https://doi.org/10.30598/bioedupat.v1.i2.pp45-49

\section{INTRODUCTION}

The male reproductive system consists of the hypothalamus, anterior pituitary and testes. Disorders of each of these organs can cause infertility and reduce secondary sexual characteristics. Disorders of the testes can affect the Leydig cells and the Sertoli cells which play a role in the production of testosterone and the maturation of spermatozoa. Damage to the male reproductive system can lead to infertility (Roychoudhury et al. 2021). Infertility is a condition in which the wife does not get pregnant after more than one year of regular sexual intercourse without using a contraceptive method. The main cause of male infertility in developing countries is spermatogenesis (Anshuka et al. 2021). Male infertility is caused by low sperm motility (asthenozoospermia), the number of spermatozoa (oligoszoopermia), sperm morphological abnormalities (teratozoospermia) (Zhang et al. 2021). Nigella sativa has compounds that have antioxidant effects. The physiological function of antioxidants is 
to prevent damage to cellular components due to free radicals (Salima et al. 2021). The production of free radicals occurs continuously in all cells as part of normal cell function. If there is excessive free radical production, it will cause oxidative stress (Marija et al. 2021). Oxidative stress plays an important role in the pathophysiology of various diseases (Zhang et al. 2021). Based on the results of research, Nigella sativa is useful as an antioxidant, anticancer, anti-inflammatory, anti-cholesterol, antihistamine, antibiotic, immunomodulator and so on. The oil content of nigella sativa consists of alpha pinen (13.75\%), limonene $(2.55 \%)$, p-cymen (43.58\%), carvacrol $(2.53 \%)$, tymoquinone (1.65\%), Linoleic acid $(25 \%)$, oleic acid $(12 \%)$, palmitic acid $(2.84 \%)$, stearic acid $(0.34 \%)$, linoleic acid $(0.35 \%)$ and meristid acid $(0.35 \%)$, carbohydrates, fats, vitamins, mineral elements, protein, unsaturated fatty acids such as linoleic, oleic and essential fatty acids such as phospholipids, phosphatidylcholine, phosphatidyletholamin, phosphatidyl serine, calcium, iron and potassium (Sanaz et al. 2021).

Research of Nigella sativa was able to improve the quality of spermatozoa in several experimental animals. This is evidenced by research which states that there is an increase in testosterone levels, sperm motility, seminal vesicle weight, and spermatozoa quality in rats with hyperlipedemia (Kristian et al. 2021). This study aims to determine the distribution of nigella sativa oil on the motility and number of spermatozoa in male Wistar rats.

\section{METHODS}

This research is a laboratory experimental study. The research design used experimental design. Randomized posttest only control group design using experimental animals as research objects. The research process lasted for 40 days starting January 27 to March 6, 2021 using 24 Wistar rats. Motility and sperm count examination were carried out at the laboratory Biology Universitas Pattimura. The experimental animals were adapted to cages for 1 week and divided into 4 groups consisting of a control group of 6 male wistar rats given distilled water and a treatment group of 3 groups which were given oil nigella sativa for 16 days. Consisting of group 1 with a dose of $150 \mathrm{mg} / \mathrm{kgbw}$, group 2 dose of $250 \mathrm{mg} / \mathrm{kgbw}$, and group 3 dose of $350 \mathrm{mg} / \mathrm{kgbw}$. The results of the examination and calculation of research data were analyzed using a Program SPSS 20 for windows. The significance value in this study is that the analyzed variables have a $p$ value $<0.05$.

\section{RESULTS AND DISCUSSION}

\section{Observation of motility and number of spermatozoa}

After the treatment of nigella sativa oil for 16 days, male wistar rats were take analysis of motility and number of spermatozoa. Wistar rat were anesthetized with ether then their defferent ducts were taken by clamping the ampulla of the defferent ducts and cauda epididymis, then cut approximately $1 \mathrm{~cm}$ from the cauda epididymis clamp and defferent ducts, after being cut they were sorted and collected for sperm fluid then mixed with EBSS as much as 2 milli microns. examination of spermatozoa with $100 \mathrm{X}$ magnification at $18-240^{\circ} \mathrm{C}$ room temperature, the examination was carried out with 3 fields of view. Observation of Wistar rat spermatozoa can be seen in Figure 1.

Figure 1. Observation of Wistar rat spermatozoa (100 x Magnification)

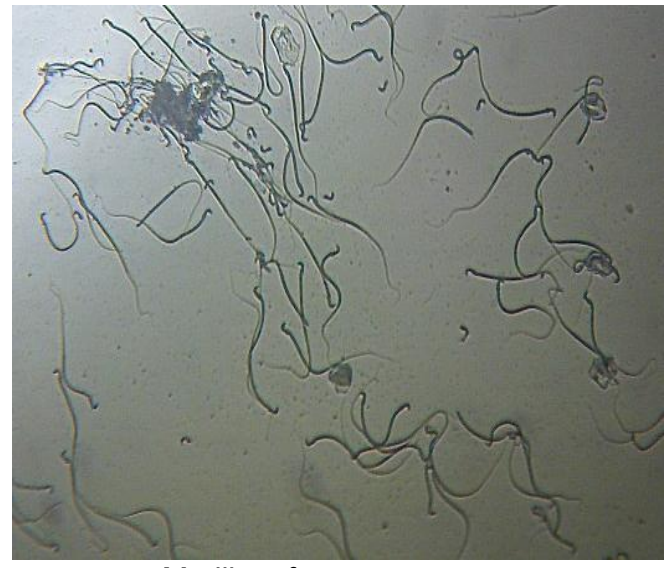

Motility of spermatozoa



the number of spermatozoa 
The results showed of the nigella sativa oil to male Wistar rats was able to increase the motility and number of spermatozoa. The results of the analysis can be seen in table 1 .

Table 1. Results of analysis motility of spermatozoa

\begin{tabular}{ll}
\hline Treatment & Mean \pm Std. Deviation \\
\hline Control & $21.67 \pm 9.832$ \\
$150 \mathrm{mg} / \mathrm{kgbw}$ & $30.67 \pm 8.165$ \\
$250 \mathrm{mg} / \mathrm{kgbw}$ & $40.67 \pm 17.512$ \\
$350 \mathrm{mg} / \mathrm{kgbw}$ & $52.33 \pm 13.292$ \\
\hline
\end{tabular}

Average value of motility spermatozoa in the control group was $21.67 \pm 9.832$ ) lower than the three treatments of nigella sativa oil. In treatment $350 \mathrm{mg} / \mathrm{kgbw}$ is much higher $(52.33 \pm 13,292)$ compared to treatment 250 $\mathrm{mg} / \mathrm{kgbw}(40.67 \pm 17,512)$ and treatment $150 \mathrm{mg} / \mathrm{kgbw}(30.67 \pm 8,165)$. This study shows that giving negella sativa oil at a dose of $350 \mathrm{mg} / \mathrm{kgbw}$ for 16 days can increase motility of spermatozoa in male Wistar rats. To determine the difference in motility of spermatozoa in each treatment of nigella sativa oil for 16 days, a Mann-Whitney test was performed. The results of the Mann-Whitney test analysis can be seen in table 2 .

Table 2. Mann-Whitney of motility Spermatozoa

\begin{tabular}{lll}
\hline Group & Treatment & P value \\
\hline Control & $150 \mathrm{mg} / \mathrm{kgbw}$ & 0.115 \\
& $250 \mathrm{mg} / \mathrm{kgbw}$ & 0.137 \\
& $350 \mathrm{mg} / \mathrm{kgbw}^{*}$ & 0.021 \\
\hline $150 \mathrm{mg} / \mathrm{kgbw}$ & $250 \mathrm{mg} / \mathrm{kgbw}$ & 0.104 \\
& $350 \mathrm{mg} / \mathrm{kgbw}^{*}$ & 0.002 \\
\hline $250 \mathrm{mg} / \mathrm{kgbw}$ & $350 \mathrm{mg} / \mathrm{kgbw}^{*}$ & 0.005 \\
\hline Significant $P<0.05$ & &
\end{tabular}

Based on the table, it can be seen that in the control with a dose of $350 \mathrm{mg} / \mathrm{kgbw}(p=0.021)$ there was a significant difference $(p<0.05)$, while the control was with a dose of $150 \mathrm{mg} / \mathrm{kgbw}(p=0.115)$ and $250 \mathrm{mg} / \mathrm{kgbw}$ (0.137). ) there is no significant difference. In dose $150 \mathrm{mg} / \mathrm{kgbw}$ with the dose $350 \mathrm{mg} / \mathrm{kgbw}(p=0.002)$ and the dose $250 \mathrm{mg} / \mathrm{kgbw}$ with a dose of $350 \mathrm{mg} / \mathrm{kgbw}(\mathrm{p}=0.005)$ there was a significant difference.

Table 3. Results of analysis number of spermatozoa

\begin{tabular}{ll}
\hline Treatment & Rata-Rata \pm Std. Deviasi \\
\hline Control & $130.83 \pm 41.877$ \\
$150 \mathrm{mg} / \mathrm{kgbw}$ & $140.83 \pm 32.568$ \\
$250 \mathrm{mg} / \mathrm{kgbw}$ & $187.50 \pm 74.538$ \\
$350 \mathrm{mg} / \mathrm{kgbw}$ & $199.67 \pm 23.480$ \\
\hline
\end{tabular}

Average number of spermatozoa in the control $(130.83 \pm 41.877)$ was much lower than that in the treatment of nigella sativa oil. The average higher number of spermatozoa was found in the dose $350 \mathrm{mg} / \mathrm{kgbw}$ (199.67 \pm 23.480 ), followed by the dose $250 \mathrm{mg} / \mathrm{kgbw}(187.50 \pm 74.538)$ and the dose $150 \mathrm{mg} / \mathrm{kgbw}$ $(140.83 \pm 32.568)$. This study indicated that the provision of nigella sativa oil increased the number of spermatozoa. The treatment of nigella sativa oil to rats for 16 days was then analyzed using the Mann-Whitney test. The results of the Mann-Whitney test analysis can be seen in table 4 .

Table 4. Mann-Whitney test for the number of spermatozoa

\begin{tabular}{lll}
\hline Group & Dose & P value \\
\hline Control & $150 \mathrm{mg} / \mathrm{kgbw}$ & 0.215 \\
& $250 \mathrm{mg} / \mathrm{kgbw}$ & 0.337 \\
& $350 \mathrm{mg} / \mathrm{kgbw}^{*}$ & 0.019 \\
\hline $150 \mathrm{mg} / \mathrm{kgbw}$ & $250 \mathrm{mg} / \mathrm{kgbw}$ & 0.404 \\
& $350 \mathrm{mg} / \mathrm{kgbw}^{*}$ & 0.009 \\
\hline $250 \mathrm{mg} / \mathrm{kgbw}$ & $350 \mathrm{mg} / \mathrm{kgbw}^{*}$ & 0.012 \\
\hline
\end{tabular}


Based on the table above, it can be seen that in the control with a dose of $350 \mathrm{mg} / \mathrm{kgbw}(p=0.019)$ there was a significant difference $(p<0.05)$, control with a dose of $150 \mathrm{mg} / \mathrm{kgbw}(p=0.215)$ and a dose $250 \mathrm{mg} / \mathrm{kgbw}$ (0.337). ) there is not significant difference. In the dose $150 \mathrm{mg} / \mathrm{kgBB}$ with the dose $350 \mathrm{mg} / \mathrm{kgbw}(p=0.009)$ and the dose $250 \mathrm{mg} / \mathrm{kgbw}$ with a dose $350 \mathrm{mg} / \mathrm{kgbw}(\mathrm{p}=0.012)$ there was a significant difference.

\section{DISCUSSION}

The low number of motility and number of spermatoza in the control group compared to the treatment of nigella sativa oil was due to the cytochrome P450s enzymes present in the animal body biologically causing the production of ROS (Seungjin et al. 2020). Excessive production of ROS causes oxidative stress which affects antioxidant enzymes which consist of enzymatic components of the body's defense system, such as superoxide dismutase (SOD), catalase, glutathione peroxidase (GPx) and glutathione-stransferase (GST) (Alugoju et al. 2015). In wistar rate that were not given nigella sativa oil caused an increase in ROS compounds. ROS plays a role in oxidative stress such as superoxide (O2-), hydrogen peroxide ( $\mathrm{H} 2 \mathrm{O} 2)$, peroxyl (ROO-), hydroxyl $(\mathrm{OH}-)$ and nitrogen oxide derivatives such as (NO-), peroxinitate (ONOO-) (Elisa et al. 2021). Increased ROS in the tissue that produces spermatozoa can cause abnormal spermatozoa. In addition, free radicals also stimulate apoptosis by involving a series of events that occur both in the cytoplasm and in the cell nucleus (Ismail et al. 2020). In the cytoplasm it activates caspase and in the cell nucleus chromatin condensation occurs, the nuclear sheath breaks and DNA fragmentation occurs for subsequent apoptosis (Ralf \& Kristian, 2020). Oxidative stress and apoptosis are involved in mediating the DNA damage of spermatozoa. Intact spermatozoa DNA is an important condition for fertilization. Spermatozoa DNA damage is closely related to sperm function and male infertility. Spermatozoa in infertile men have been shown to have abnormal sperm (Ralf \& Kristian, 2020).

Figure 2. Role of ROS on Spermatozoa DNA Damage (Ralf \& Kristian, 2020).

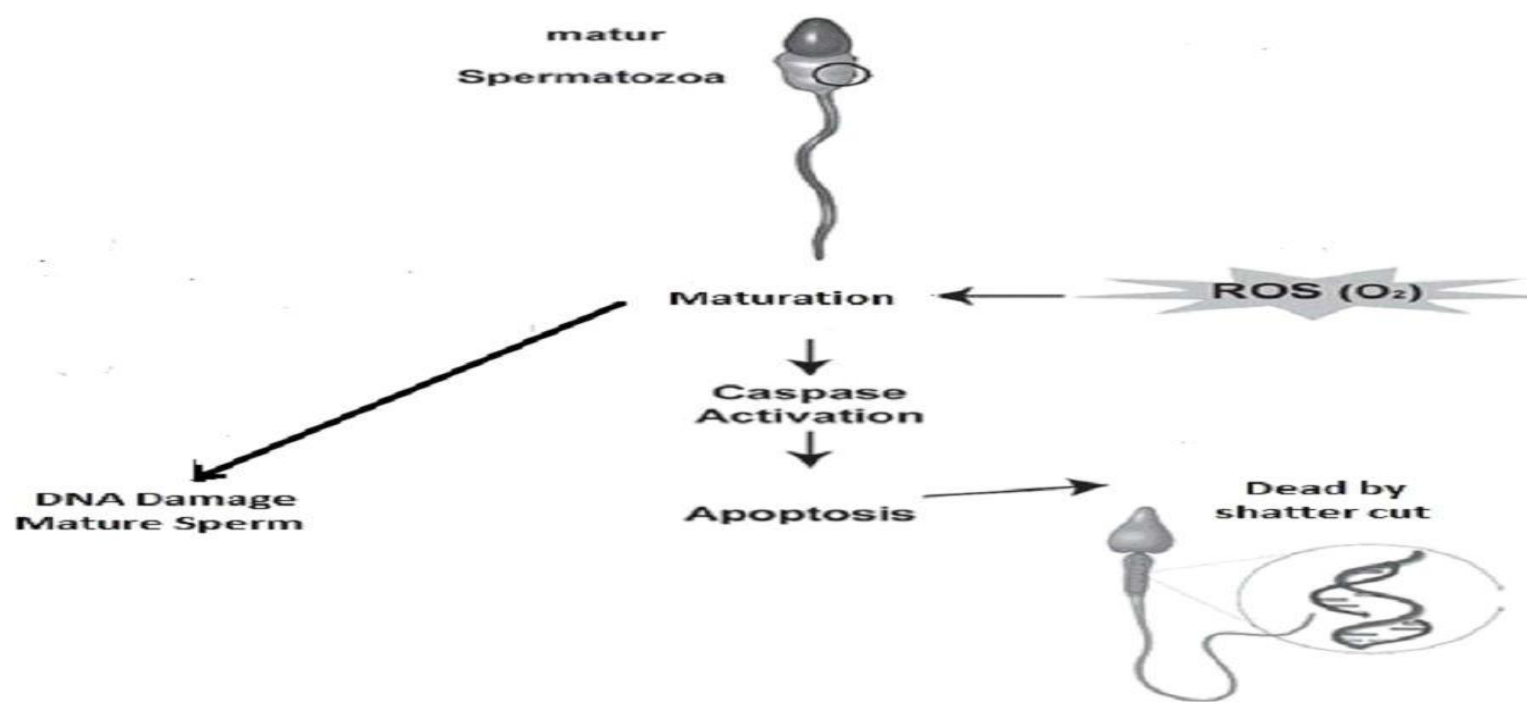

The body has its own mechanism that can neutralize the dangers of free radicals with an antioxidant system, but if free radicals exceed the amount of antioxidants in the body it will cause cell damage (Zhang et al. 2021). The results of nigella sativa oil to male wistar rats in this study were higher than that of the control group. This is because Nigella sativa oil has antioxidant and immunodulatory effects where the physiological function is to prevent cellular damage due to free radicals and can repair cellular damage. Antioxidants play a role by catalyzing free radicals by the enzymes SOD catalase and peroxidase, binding pro-oxidants and cleaning ROS in the body's metabolism. Nigella sativa oil has thymoquinone compounds that act as immunodulators and antioxidants by activating antioxidant enzymes such as superoxide dismutase (SOD), catalase, glutathione peroxidase (GPx) and glutathione-Stransferase (GST) (Mehdi et al. 2020). 


\section{CONCLUSION}

The administration of Nigella sativa oil at a dose of $350 \mathrm{mg} / \mathrm{kgbw}$ for 16 days increased the motility and the number of spermatozoa was higher than the dose of $250 \mathrm{mg} / \mathrm{kgbw}$ and $150 \mathrm{mg} / \mathrm{kgbw}$ in male Wistar rats.

\section{ACKNOWLEDGMENT}

The financial support for this research and development was provided by the Industrial Research and Technology Development Program Faculty of Teacher Training and Education, Pattimura University, of Indonesia No: 1590/UN13/SK/2020.

\section{REFERENCES}

Anshuka., Venkadalakshmi, V., Das, Karobi., Arora, A. 2021. Psychosocial problems among couples with primary infertility. Nursing and Midwifery Research Journal; Chandigarh. 17 (1) 46-52.

Alugoju, P., Dinesh, B. Jestadi., \& Latha, P. 2015. Free Radicals: Properties, Sources, Targets, and Their Implication in Various Diseases. Indian Journal Clinical Biochemistry. 30(1) 11-26.

Elisa, S., Mads, H., Clausen., \& Luca, L. 2021. Small-Molecule Inhibitors of Reactive Oxygen Species Production. Journal Medicine Chemistry. 64 (9) 5252-5275

Marija, D.J., Aljosa, D. M., Slobodan, M. M., Branislava, U. S. 2021. Oxidative stress and its role in cancer. Journal of cancer research and therapeutics. 17 (1) 22-28.

Mehdi, Sharifi-Rad., Nanjangud. V., Anil, K., Paolo, Z., Elena, M. V., Luciana, D., Elisa, P., Jovana, R., Atrick, V. T.F., Okou, E. A., Ilaria, P., Abhay, P. M., Manisha, N., Youssef, El. Rayess., Marc, El. B., Letizia, P., Marcello, I., Natália, M., Miquel, M., Anca, Oana. D., William, N. Setzer., Daniela, C., William, C. Cho., \& Javad, Sharifi-Rad. 2020. Lifestyle, Oxidative Stress, and Antioxidants: Back and Forth in the Pathophysiology of Chronic Diseases. Frontiers in Physiology. 2 (6) 34-46.

Roychoudhury, S., Chakraborty S., Choudhury, A. P., Das, A., Kumar, Jha Niraj., Petr, Slama., Monika, Nath., Peter, M., Janne, R., \& Kumar K. K. 2021. Environmental Factors-Induced Oxidative Stress: Hormonal and Molecular Pathway Disruptions in Hypogonadism and Erectile Dysfunction. Journal antioxidants. 2 1-39.

Ralf, Henkel., \& Kristian, Leisegang. 2020. Origins of Sperm DNA Damage. Male Infertility. pp 361-375. Ismail, S., Pinar, T. S., Burcu, Gul. Baykalir., Tuba, P.Ak., Seyma, Ozer K., Mine, Y.. 2020. Bee glue (propolis) improves reproductive organs, sperm quality and histological changes and antioxidant parameters of testis tissues in rats exposed to excess copper. Andrologia 52, (4)

Salima, T., Ouijdane, B., Mohamed, B., Ibrahim, El. M., Mostafa, M. 2021. Phytochemical Profile and Antioxidant Activity of Nigella sativa Growing in Morocco. The Scientific World Journal. 3 (5) 1-12.

Seungjin, N., Ara Go., Da Bin Kim., Minjeong, Park., Hee Won Jeon., \& Bonglee, Kim. 2020. Role of Antioxidant Natural Products in Management of Infertility: A Review of Their Medicinal Potential. Antioxidants. 9 (10) $30-45$

Sanaz, A., Ali Es-haghi., Homa, M. 2021. Evaluation of anti-cancer and antioxidant properties of nanoemulsions synthesized by Nigella Sativa L. Tincture. 8 (1) 57-64.

Kristian, L., Walid, A., Ralf, H. 2021. The effect of Nigella sativa oil and metformin on male seminal parameters and testosterone in Wistar rats exposed to an obesogenic diet. Biomedicine \& Pharmacotherapy 133 67-89.

Zhang, F., Li, J., Liang, Z., Jinggen Wu, Lejun Li., Chong Chen., Fan Jin \& Yonghong T. 2021. Sperm DNA fragmentation and male fertility: a retrospective study of 5114 men attending a reproductive center. Journal Assist Reprod Genetic. 21 (5) 20-35. 